Pacific Journal of Mathematics

CONTINUOUS SPECTRA OF SECOND-ORDER DIFFERENTIAL 


\title{
CONTINUOUS SPECTRA OF SECOND-ORDER DIFFERENTIAL OPERATORS
}

\author{
DoN HiNTON
}

We consider the differential operator $l(y)=y^{\prime \prime}+q y$, where $q$ is a positive, continuously differentiable function defined on a ray $[a, \infty)$. The operator $l$ determines, with appropriate restrictions, self-adjoint operators defined in the hilbert space $\mathscr{L}_{2}[a, \infty)$ of quadratically summable, complexvalued functions on $[a, \infty)$. In this note, we prove that if $L$ is such a selfadjoint operator, then the conditions $q(t) \rightarrow \infty$ and $q^{\prime}(t) q(t)^{-1 / 2} \rightarrow 0$ as $t \rightarrow \infty$ are sufficient for the continuous spectrum $C(L)$ of $L$ to cover the entire real axis.

Similar results are well-known; however, monotonicity conditions on $q$ and $q^{\prime}$ are usually required. For example, in [1], p. 116, it is proved that if $q$ tends monotonically to $\infty$ as $t \rightarrow \infty$, preserving the direction of convexity for large $t$, then the condition $q^{\prime}(t) q(t)^{-1 / 2} \rightarrow 0$ as $t \rightarrow \infty$ is sufficient to imply $C(L)=(-\infty, \infty)$ for every self-adjoint operator $L$ determined by $l$.

THEOREM. If $q(t) \rightarrow \infty$ as $t \rightarrow \infty, q^{\prime}(t) q(t)^{-1 / 2} \rightarrow 0$ as $t \rightarrow \infty$, and $L$ is a self-adjoint operator in $\mathscr{L}_{2}[a, \infty)$ determined by $l$, then $C(L)=$ $(-\infty, \infty)$.

Proof. To prove that the real number $\lambda$ belongs to $C(L)$, it is sufficient to construct a bounded noncompact sequence $y_{1}, y_{2}, \cdots$ such that $\left\|(L-\lambda) y_{n}\right\| \rightarrow 0$ as $n \rightarrow \infty$. The domain of $L$ includes the set Cl of all $y$ satisfying (i) $y$ has compact support contained in the open interval $(a, \infty)$, (ii) $y^{\prime}$ is absolutely continuous, and (iii) $y^{\prime \prime} \in \mathscr{L}_{2}[a$, $\infty$ ) (cf. [3], Chapter V). Hence, it follows that $\lambda \in C(L)$, if we prove that for each $\eta>0$ and $N>a$, there is a nontrivial $y \in \mathscr{l l}$ such that the support of $y$ is contained in $[N, \infty)$ and $\|(L-\lambda) y\|<\eta \| y /$. To establish this, we recall Lemma 2 of [2]:

Suppose $f$ is a continuously differentiable positive function on $[b, \infty)$, and $f^{\prime}(t) f(t)^{-1 / 2} \rightarrow 0$ as $t \rightarrow \infty$. If $\varepsilon$ and $K$ are positive numbers, then there is a number $B$ such that if $t$ and $s$ are $\geqq B$ and $|t-s| \leqq$ $K f(s)^{1 / 2}$, then $\left|f(t) f(s)^{-1}-1\right|<\varepsilon$.

We choose $0<\varepsilon<\eta^{2} / 25, K>6400 / \eta^{2}$ (assume $\eta<1$ ), and apply the lemma to $f=q-\lambda$ on an interval $[b, \infty)$ such that $f(t) \geqq \Pi^{2}$ for $t \geqq b$. Let $s_{0} \geqq \max \{N, B\}$ be such that $\left|f^{\prime}(t)\right| f(t)^{-1 / 2}<\varepsilon$ for $t \geqq s_{0}$. 
Define $s_{1}, s_{2}, \ldots$ by

$$
s_{i+1}=s_{i}+\Pi f\left(s_{i}\right)^{-1 / 2} \quad(i=0,1, \cdots),
$$

and denote $f\left(s_{i}\right)^{1 / 2}$ by $\alpha_{i}$. Since for $s_{i} \leqq s_{0}+K \alpha_{0}$, we have $\alpha_{i}^{2} / \alpha_{0}^{2} \leqq$ $1+\varepsilon<4$, it follows that for such $s_{i}$,

$$
s_{i}-s_{0}=\sum_{j=0}^{i-1} \Pi / \alpha_{j} \geqq \Pi i / 2 \alpha_{0} ;
$$

thus there is an integer $p$ so that $s_{p} \leqq s_{0}+K \alpha_{0}<s_{p+1}$. We now construct a $y \in \mathscr{C}$ with support $\left[s_{0}, s_{p}\right]$.

Since $K>9$ and $\alpha_{i} \geqq \Pi$ for each $i$, there exist $\tau_{1}, \tau_{2} \in\left\{s_{0}, \cdots, s_{p}\right\}$ such that $s_{0}<\tau_{1}<\tau_{2}<s_{p}, \alpha_{0} \leqq \tau_{1}-s_{0} \leqq 2 \alpha_{0}, \alpha_{0} \leqq s_{p}-\tau_{2} \leqq 2 \alpha_{0}$, and $\tau_{2}-\tau_{1} \geqq K \alpha_{0} / 2$. Define $h$ and $g$ on $[a, \infty)$ to be zero exterior to $\left[s_{0}, s_{p}\right]$ and otherwise by

$$
g(t)=(-1)^{i} \alpha_{i}^{-1} \sin \alpha_{i}\left(t-s_{i}\right) \text { for } s_{i} \leqq t \leqq s_{\imath+1}, \quad(i=0, \cdots, p-1)
$$

and

$$
h(t)= \begin{cases}\left(t-s_{0}\right) /\left(\tau_{1}-s_{0}\right), & s_{0} \leqq t \leqq \tau_{1}, \\ 1, & \tau_{1} \leqq t \leqq \tau_{2}, \\ \left(s_{p}-t\right) /\left(s_{p}-\tau_{2}\right), & \tau_{2} \leqq t \leqq s_{p} .\end{cases}
$$

If $y=g h$, then a calculation yields that $y \in \mathscr{A}$.

Since $\varepsilon<1 / 4$, from the lemma above we conclude that

$$
\left.f(t) / f(s)=\left\{f(t) / f\left(s_{0}\right)\right\} /\left\{f(s) / f\left(s_{0}\right)\right\}<(5 / 4) / 3 / 4\right)<2
$$

for all $t, s \in\left[s_{0}, s_{p}\right]$. Applying the mean value theorem, it follows that for $t \in\left[s_{i}, s_{i+1}\right]$,

$$
\begin{aligned}
\left|f(t)-f\left(s_{i}\right)\right| & =\left|f^{\prime}\left(t^{*}\right)\left(t-s_{i}\right)\right| \\
& \leqq\left\{\left|f^{\prime}\left(t^{*}\right)\right| f\left(t^{*}\right)^{-1 / 2}\right\}\left\{\Pi f\left(t^{*}\right)^{1 / 2} f\left(s_{i}\right)^{-1 / 2}\right\} \\
& <\Pi(2)^{1 / 2} \varepsilon<5 \varepsilon .
\end{aligned}
$$

For $t \in\left[s_{i}, s_{i+1}\right] \subset\left[s_{0}, \tau_{1}\right]$, we have by application of (1), (2), and $\tau_{1}-s_{0} \geqq \alpha_{0}$ that

$$
\begin{aligned}
\left|y^{\prime \prime}(t)+f(t) y(t)\right|= & \mid 2\left(\tau_{1}-s_{0}\right)^{-1}(-1)^{i} \cos \alpha_{i}\left(t-s_{i}\right) \\
& +\left(t-s_{0}\right)\left(\tau_{1}-s_{0}\right)^{-1}\left[f(t)-f\left(s_{i}\right)\right] g(t) \mid \\
\leqq & 2\left(\tau_{1}-s_{0}\right)^{-1}+5 \varepsilon \alpha_{i}^{-1} \\
< & 2 / \alpha_{0}+5(2)^{1 / 2} / \alpha_{0}<10 / \alpha_{0} .
\end{aligned}
$$

From this inequality and $\tau_{1}-s_{0} \leqq 2 \alpha_{0}$, it follows that

$$
\int_{s_{0}}^{\tau_{1}}\left|y^{\prime \prime}+f y\right|^{2} d t \leqq\left(100 / \alpha_{0}^{2}\right)\left(\tau_{1}-s_{0}\right) \leqq 200 / \alpha_{0} .
$$


Similarly, we have

$$
\int_{\tau_{2}}^{s_{p}}\left|y^{\prime \prime}+f y\right|^{2} d t \leqq 200 / \alpha_{0}
$$

For $\left[s_{i}, s_{i+1}\right] \subset\left[\tau_{1}, \tau_{2}\right]$, the definition of $y$ and (1) yield

$$
\int_{s_{i}}^{s_{i+1}} y^{2} d t=\left(s_{i+1}-s_{i}\right) / 2 \alpha_{\imath}^{2} \geqq\left(s_{i+1}-s_{i}\right) / 4 \alpha_{0}^{2},
$$

hence, this inequality and $\left(\tau_{2}-\tau_{1}\right) \geqq K \alpha_{0} / 2$ imply that

$$
\int_{\tau_{1}}^{\tau_{2}} y^{2} d t \geqq\left(\tau_{2}-\tau_{1}\right) / 4 \alpha_{0}^{2} \geqq K / 8 \alpha_{0} \text {. }
$$

Since on $\left[s_{i}, s_{i+1}\right]$,

$$
\left|y^{\prime \prime}(t)+f(t) y(t)\right|=\left|\left[f(t)-f\left(s_{i}\right)\right] y(t)\right| \leqq 5 \in|y(t)|,
$$

we have

$$
\begin{aligned}
& \int_{s_{i}}^{s_{i+1}}\left|y^{\prime \prime}+f y\right|^{2} d t<25 \varepsilon^{2} \int_{s_{i}}^{s_{i+1}} y^{2} d t ; \text { thus } \\
& \left\{\int_{\tau_{1}}^{\tau_{2}}\left|y^{\prime \prime}+f y\right|^{2} d t\right\}\left\{\int_{\tau_{1}}^{\tau_{2}} y^{2} d t\right\}^{-1}<25 \varepsilon^{2}<\varepsilon .
\end{aligned}
$$

From the definition of $\varepsilon$ and $K,(3)$, (4), (5), and (6), we obtain

$$
\left\{\int_{s_{0}}^{s_{p}}\left|y^{\prime \prime}+f y\right|^{2} d t\right\}\left\{\int_{s_{0}}^{s_{p}} y^{2} d t\right\}^{-1}<\{3200 / K\}+\varepsilon<\eta^{2}
$$

therefore the proof is complete.

In [3], p. 235, asymptotic methods are used to obtain criteria for $C(L)=(-\infty, \infty)$. In this development much of the argument depends on the divergent integral $\int_{a}^{\infty} q^{-1 / 2} d t=\infty$. The condition $q^{\prime}(t) q(t)^{-1 / 2} \rightarrow 0$ as $t \rightarrow \infty$ implies the divergence of this integral. We raise the following question for a class $C^{(1)}$ function $q$ : Are the conditions $q(t) \rightarrow \infty$ as $t \rightarrow \infty$ (perhaps monotonically) and $\int_{a}^{\infty} q^{1 / 2} d t=\infty$ sufficient to imply $C(L)=(-\infty, \infty) ?$

\section{REFERENCES}

1. I. M. Glazman, Direct methods of qualitative spectral analysis of singular differential operators, Israel program for scientific translation, Jerusalem, 1965.

2. D. B. Hinton, Some stability conditions for a nonlinear differential equation, Trans. Amer. Math. Soc. 139 (1969), 349-358.

3. M. A. Naimark, Linear differential operators, part II, Ungar, New York, 1968.

Received October 3, 1969.

UNIVERSITY OF GEORGIA

Athens, Georgia 



\section{PACIFIC JOURNAL OF MATHEMATICS}

\section{EDITORS}

\author{
H. SAMELSON \\ Stanford University \\ Stanford, California 94305 \\ Richard Pierce \\ University of Washington \\ Seattle, Washington 98105
}

J. DUGUNDJI

Department of Mathematics

University of Southern California

Los Angeles, California 90007

RICHARD ARENS

University of California

Los Angeles, California 90024

\section{ASSOCIATE EDITORS}
E. F. BECKENBACH
B. H. NEUMaNN
F. WOLE
K. YosHIDA

\section{SUPPORTING INSTITUTIONS}

\author{
UNIVERSITY OF BRITISH COLUMBIA \\ CALIFORNIA INSTITUTE OF TECHNOLOGY \\ UNIVERSITY OF CALIFORNIA \\ MONTANA STATE UNIVERSITY \\ UNIVERSITY OF NEVADA \\ NEW MEXICO STATE UNIVERSITY \\ OREGON STATE UNIVERSITY \\ UNIVERSITY OF OREGON \\ OSAKA UNIVERSITY \\ UNIVERSITY OF SOUTHERN CALIFORNIA
}

\author{
STANFORD UNIVERSITY \\ UNIVERSITY OF TOKYO \\ UNIVERSITY OF UTAH \\ WASHINGTON STATE UNIVERSITY \\ UNIVERSITY OF WASHINGTON

$* * *{ }^{*} *{ }^{*}$
AMERICAN MATHEMATICAL SOCIETY
CHEVRON RESEARCH CORPORATION
TRW SYSTEMS \\ NAVAL WEAPONS CENTER
}

The Supporting Institutions listed above contribute to the cost of publication of this Journal. but they are not owners or publishers and have no responsibility for its content or policies.

Mathematical papers intended for publication in the Pacific Journal of Mathematics should be in typed form or offset-reproduced, (not dittoed), double spaced with large margins. Underline Greek letters in red, German in green, and script in blue. The first paragraph or two must be capable of being used separately as a synopsis of the entire paper. The editorial "we" must not be used in the synopsis, and items of the bibliography should not be cited there unless absolutely necessary, in which case they must be identified by author and Journal, rather than by item number. Manuscripts, in duplicate if possible, may be sent to any one of the four editors. Please classify according to the scheme of Math. Rev. 36, 1539-1546. All other communications to the editors should be addressed to the managing editor, Richard Arens, University of California, Los Angeles, California, 90024.

50 reprints are provided free for each article; additional copies may be obtained at cost in multiples of 50 .

The Pacific Journal of Mathematics is published monthly. Effective with Volume 16 the price per volume (3 numbers) is $\$ 8.00$; single issues, $\$ 3.00$. Special price for current issues to individual faculty members of supporting institutions and to individual members of the American Mathematical Society: $\$ 4.00$ per volume; single issues $\$ 1.50$. Back numbers are available.

Subscriptions, orders for back numbers, and changes of address should be sent to Pacific Journal of Mathematics, 103 Highland Boulevard, Berkeley, California, 94708.

PUBLISHED BY PACIFIC JOURNAL OF MATHEMATICS, A NON-PROFIT CORPORATION

Printed at Kokusai Bunken Insatsusha (Internatıonal Academic Printing Co., Ltd.), 7-17, Fujimi 2-chome, Chiyoda-ku, Tokyo, Japan. 


\section{Pacific Journal of Mathematics}

\section{Vol. 33, No. 3 \\ May, 1970}

Charles A. Akemann, Approximate units and maximal abelian

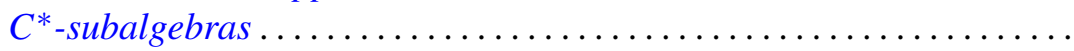

Gail Atneosen, Wild points of cellular arcs in 2-complexes in $E^{3}$ and cellular hulls

John Logan Bryant and De Witt Sumners, On embeddings of 1-dimensional

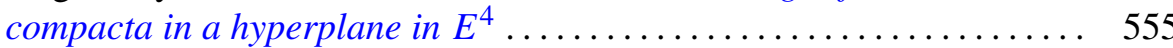

H. P. Dikshit, On a class of Nörlund means and Fourier series.......... 559

Nancy Dykes, Generalizations of realcompact spaces .............. 571

Hector O. Fattorini, Extension and behavior at infinity of solutions of certain linear operational differential equations .................. 583

Neal David Glassman, Cohomology of nonassociative algebras .......... 617

Neal Hart, Ulm's theorem for Abelian groups modulo bounded groups . . . . 635

Don Barker Hinton, Continuous spectra of second-order differential

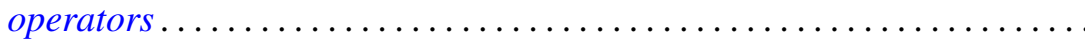

Donald Gordon James, On Witt's theorem for unimodular quadratic forms. II ............................................. 645

Melvin F. Janowitz, Principal multiplicative lattices................ 653

James Edgar Keesling, On the equivalence of normality and compactness in hyperspaces .................................... 657

Adalbert Kerber, Zu einer Arbeit von J. L. Berggren über ambivalente Gruppen

Keizō Kikuchi, Various $m$-representative domains in several complex variables

Jack W. Macki and James Stephen Muldowney, The asymptotic behaviour of solutions to linear systems of ordinary differential equations ....

Andy R. Magid, Locally Galois algebras . . . .

T. S. Ravisankar, On differentiably simple algebras......

Joseph Gail Stampfli, The norm of a derivation ..

Francis C.Y. Tang, On uniqueness of central decompositions of groups ...

749

Robert Charles Thompson, Some matrix factorization theorems. I .

763

Robert Charles Thompson, Some matrix factorization theorems. II . . 